\title{
Evaluation of water requirement, commercial quality, and yield response factor of gladiolus produced with automated irrigation in different growing periods
}

\section{Avaliação da necessidade hídrica, qualidade comercial e fator de resposta da produção de gladíolo produzido com irrigação automatizada em diferentes épocas de cultivo}

\author{
Jaqueline Jesus Santana dos Santos ${ }^{1 *} \mathbb{D}$, Rogério Gomes Pêgo ${ }^{2} \mathbb{D}$, Beatriz Rodrigues Monteiro Couto ${ }^{1}$, \\ Mateus Marques Bueno ${ }^{1} \mathbb{D}$, Daniel Fonseca de Carvalho ${ }^{1}$
}

\author{
'Universidade Federal Rural do Rio de Janeiro/UFRRJ, Departamento de Engenharia, Instituto de Tecnologia, Seropédica, RJ, Brasil \\ ${ }^{2}$ Universidade Federal Rural do Rio de Janeiro/UFRRJ, Instituto de Agronomia, Seropédica, RJ, Brasil \\ *Corresponding author: jaqueline_jjss@hotmail.com \\ Received in July 13, 2020 and approved in October 08, 2020
}

\begin{abstract}
Water management and meteorological conditions during the cropping phase play an essential role in maintaining the commercial quality of cut flowers. This study evaluates water requirement, sensitivity to water deficit, and commercial quality of gladiolus 'Amsterdam' produced with automated irrigation in different growing periods. The experimental design was in randomized blocks with five replicates and consisted of the growing period factors (winter/spring 2018 and autumn/winter 2019) and the irrigation level factors (45\% - L1, $60 \%-\mathrm{L} 2,80 \%-\mathrm{L} 3$, and 100\% - L4 of crop water requirement). An automatic irrigation controller was used for irrigation management. At the harvest point, we evaluated the stems for the diameter, number of flowers, spike length, and floral stem length. We also evaluated stomatal conductance, leaf area, and duration of phenological phases on degree-days. The application of 100\% crop water requirement using an automatic irrigation controller in the autumn/winter cycle results in better commercial classification. The treatment with $45 \%$ of the crop water requirement extended the total duration of the cycle. In conclusion, flower stems of better commercial classification are obtained with $100 \%$ of crop water requirement during the autumn/winter cycle.
\end{abstract}

Index terms: Gladiolus x grandiflorus Hort.; irrigation water management; degree-days; protected cultivation.

\section{RESUMO}

O manejo da irrigação e as condições meteorológicas durante a fase de cultivo desempenham um papel essencial na manutenção da qualidade comercial de flores de corte. Este estudo avalia a necessidade de água, a sensibilidade ao déficit hídrico e a qualidade comercial do gladíolo <Amsterdam' produzido com irrigação automatizada em diferentes períodos de crescimento. O delineamento experimental foi blocos casualizados com cinco repetições, composto pelo fator época de plantio (inverno/primavera de 2018 e outono/inverno de 2019) e o fator níveis de irrigação ( $45 \%$ - L1, $60 \%$ - L2, 80\% - L3, 100\% - L4 da necessidade hídrica da cultura). A irrigação foi feita com uso do acionador automático para irrigação (AAI). No ponto de colheita nós avaliamos as hastes quanto ao diâmetro, número de flores, comprimento do pendão e da haste floral. Foram realizadas também avaliações de condutância estomática, área foliar e duração das fases fenológicas em graus-dias. A aplicação de $100 \%$ da necessidade hídrica da cultura em cultivo usando o acionador automático de irrigação no outono/inverno resulta em melhor classificação comercial. O tratamento correspondente a $45 \%$ da necessidade hídrica da cultura estendeu a duração total do ciclo do gladíolo. Hastes florais de melhor qualidade comercial são obtidas com $100 \%$ da necessidade hídrica da cultura durante o cultivo de outono/inverno.

Termos para indexação: Gladiolus x grandiflorus Hort.; manejo da água de irrigação; graus-dia; cultivo protegido.

\section{INTRODUCTION}

Flower quality is of extreme importance in producing cut flowers for commercial purposes and is indicated by some visual characteristics, longevity, and commercial variables based on quality standards. These standards are established by the main cooperatives of ornamental plants and cut flowers to meet the requirements of the consumer market (Cooperativa Veiling Holambra, 2019). 
Gladiolus $x$ grandiflorus Hort. is an herbaceous and bulbous ornamental plant of significant economic value (Singab et al., 2016) and is one of the main bulbous crops cultivated for cut flowers worldwide (Casares et al., 2017). Its inflorescence is a spike of varied colors that has an important market on different commemorative dates (Streck et al., 2012), and also has decorative use in various events (Schwab et al., 2018). Gladiolus can be cultivated all year round (Barbosa, 2011); however, the crop has climatic requirements that must be respected, especially concerning temperature and occurrence of extreme environmental events such as frosts, which may cause the death of floret tissues, mainly when they occur during spike formation (Schwab et al., 2015b).

In Brazil, the commercial-quality standard criteria for gladiolus established by Veiling Holambra Cooperative includes floral stem length and thickness, spike size, the absence of visual defects, and an ideal maturity point (Cooperativa Veiling Holambra, 2019), with minimum and maximum values for each characteristic.

Adequate development of crops, including ornamental plants, also depends on factors related to crop management. Hence, it is important to evaluate the extent to which the quality of gladiolus can be influenced by pre-harvest factors such as water management during production and meteorological conditions. However, the study of irrigation management in ornamental plants, mainly using low-cost irrigation systems, has received little attention compared to agricultural species of commercial importance.

From the sustainability point of view, the use of irrigation in floriculture emerges as one of the main concerns (Junqueira; Peetz, 2018). Therefore, using a low-cost automatic system based on the plant's actual water requirement is an essential part of the sustainable management of the production system.

The cultivation of gladiolus is easy and has a low cost of implementation (Paiva; Almeida, 2013); hence it is economically viable for small producers (Uhlmann et al., 2019). However, being a bulbous plant without a true stem, gladiolus is sensitive to water stress (Barbosa, 2011) and requires good irrigation management, which can be performed, preferably, through low-cost automatic systems (Gomes et al., 2017). Adequate soil moisture and environmental conditions can impact the cycle duration and promote a higher quality of plants, with a greater number of flowers, size of flowers, and greater length of stems; thus, improving the overall commercial quality of gladiolus (Pereira et al., 2016). Understanding the effect of irrigation on the gladiolus cycle is vital for farmers planning on flower production for commercial use. The peak of the market of gladiolus, similar to other ornamental plants, occurs on specific dates, such as celebratory holidays (Reis et al., 2020). As a result, high precision in production planning is required.

Regardless of sensitivity, the relationship between the lack of available water in the soil and the decrease in the potential production of a given crop throughout its cycle can be quantified using the Ky coefficient (Doorenbos; Kassam, 1979; Silva et al., 2014). Ky values $<1$ indicate that the crop can be considered more tolerant to water deficit and partially recovers from stress, showing a proportionally lower fall in production as water deficit increases (Smith; Steduto, 2012).

Thus, the main objective of this study is to evaluate the water requirement, sensitivity to water deficit, and the commercial quality of gladiolus produced with automated irrigation in different growing periods.

\section{MATERIAL AND METHODS}

The study was conducted in a greenhouse during the winter/spring (09/07/18 to $11 / 27 / 18)$ and autumn/ winter $(04 / 12 / 19$ to $07 / 04 / 19)$ periods at the Universidade Federal Rural do Rio de Janeiro. The cultivar used in the experiment was Amsterdam, which has white flowers and a cycle of approximately 75 days. The vernalized, medium-sized (circumference from 12 to 14 $\mathrm{cm})$ commercial bulbs were acquired from Terra Viva. The cultivation was carried out in $11.0 \mathrm{~L}$ pots containing substrate of medium texture in a $2: 2: 1$ proportion (volume) of sandy soil, clayey soil, and manure. The bulbs were planted in a triangular arrangement with a spacing of $10 \mathrm{~cm}$ and a depth of $10 \mathrm{~cm}$.

The experimental design was organized in randomized blocks and consisted of the irrigation level factors $(45 \% / \mathrm{L} 1,60 \% / \mathrm{L} 2,80 \% / \mathrm{L} 3$, and $100 \% / \mathrm{L} 4$ of crop water requirement) and the growing period factors (winter/spring and autumn/winter). The area was divided into five blocks with a spacing of $60 \mathrm{~cm}$ and comprised of 4 plots, one for each treatment. Each experimental unit (plot) consisted of four pots with three plants (spacing of $15 \mathrm{~cm})$, making a total of 12 plants per plot.

Irrigation management was carried out using two automatic controllers (AAI) (Medici et al., 2010), whose sensors were installed in the center of two pots belonging to the L4 treatment (control) group at a depth of $10 \mathrm{~cm}$. The controllers were adjusted to trigger the irrigation system when the tension in the substrate reaches approximately $-4.0 \mathrm{kPa}$. The pots 
were drip-irrigated using $0.8-\mathrm{mm}$ diameter spaghetti microtubes (PDAEXT001000354/PLASNOVA) by placing one microtube per pot in polyethylene lines (16 $\mathrm{mm}$ diameter). Irrigation levels were obtained using microtubes with lengths of 80 (L1), 60 (L2), 35 (L3), and 20 (L4) cm corresponding to flow rates of 2.6, 3.4, 4.5 , and $5.7 \mathrm{~L} \mathrm{~h}^{-1}$, respectively, at $20 \mathrm{kPa}$ pressure at the initial point of the experimental area. From the start of the experiment up to 18 days after planting (DAP), the water volume applied was the same for all pots to provide uniform emergence and development. The microtubes used during this period were $20 \mathrm{~cm}$ long.

Plants were supported using three plastic ribbons with a distance of $30 \mathrm{~cm}$ once they began to produce inflorescence. When the plants had 2 to 3 leaves (spike becomes visible) fertilization was performed by applying $1 \mathrm{~g}$ of urea and $2 \mathrm{~g}$ of potassium chloride per pot, according to Freire (2013), considering as reference the analysis of the substrate used, which revealed the following chemical characteristics: $\mathrm{pH} 6.2 ; \mathrm{Na}^{2+} 0.13$ cmolc dm ${ }^{-3} ; \mathrm{Ca}^{2+} 4.5 \mathrm{cmolc} \mathrm{dm}^{-3} ; \mathrm{Mg}^{2+} 1.9 \mathrm{cmolc} \mathrm{dm}^{-3}$; P $122 \mathrm{mg} \mathrm{dm}^{-3} ; \mathrm{K}^{+} 83 \mathrm{mg} \mathrm{dm}^{-3}$; V value $=80 \%$ for the first crop and $\mathrm{pH} 5.8 ; \mathrm{Na} 0.1 \mathrm{cmolc} \mathrm{dm}^{-3} ; \mathrm{Ca}^{2+} 3.8 \mathrm{cmolc}$ $\mathrm{dm}^{-3} ; \mathrm{Mg}^{2+} 1.6 \mathrm{cmolc} \mathrm{dm}^{-3} ; \mathrm{P} 134 \mathrm{mg} \mathrm{dm}^{3} ; \mathrm{K}^{+} 84 \mathrm{mg} \mathrm{dm}{ }^{3}$; $\mathrm{V}$ value $=76 \%$ for the second crop.

For evaluating the production cycle in degreedays, the cycle was divided into subperiods according to a phenological scale (Schwab et al., 2015a). It was classified as emergence phase (VE), vegetative phase (VE - emergence to R1 - heading), and reproductive phase (R1 - heading to R2 - blooming). The thermal sum was calculated according to the methodology proposed by Ometto (1981) by considering the basal air temperature of $6{ }^{\circ} \mathrm{C}$ (Schwab et al., 2017) and maximum basal air temperature of $40^{\circ} \mathrm{C}$ (Shillo; Hallevy, 1976), as per the following situations:

Situation 1 (Equation 1):

$\mathrm{TM}>\mathrm{Tm}>\mathrm{Tb}: \mathrm{DD}=\frac{(\mathrm{TM}-\mathrm{Tm})}{2}+(\mathrm{Tm}-\mathrm{Tb})$

Situation 2 (Equation 2):

$\mathrm{TM}>\mathrm{TB}>\mathrm{Tm}>\mathrm{Tb}:$

$\mathrm{DD}=\frac{2[(\mathrm{TM}-\mathrm{Tm})(\mathrm{Tm}-\mathrm{Tb})]+(\mathrm{TM}-\mathrm{Tm})^{2}-(\mathrm{TM}-\mathrm{TB})^{2}}{2(2 \mathrm{TM}-\mathrm{Tm})}$

Where DD is degree-days $\left({ }^{\circ} \mathrm{C}\right.$ day), TM is maximum daily air temperature $\left({ }^{\circ} \mathrm{C}\right), \mathrm{Tm}$ is minimum daily air temperature $\left({ }^{\circ} \mathrm{C}\right)$, TB is maximum basal air temperature $\left({ }^{\circ} \mathrm{C}\right), \mathrm{Tb}$ is minimum basal air temperature $\left({ }^{\circ} \mathrm{C}\right)$. Cycle duration in each treatment was counted, considering when at least $50 \%$ of the plants, within each treatment, were at the phases evaluated. The monitoring of meteorological conditions inside the greenhouse was carried out via a weather station (WatchDog 2000 Series SPECTRUM, Technologies Inc.) that recorded air temperature and relative humidity in 10 min intervals.

In the second growing period (Autumn/Winter), stomatal conductance was analyzed at 40 DAP in one plant of each of the two central pots in each plot, totaling 40 plants, with 10 plants per treatment. Readings were taken using a leaf porometer SC-1 (DECAGON DEVICES) on a clear day with no clouds, at $10 \mathrm{~h}, 12 \mathrm{~h}$, and $14 \mathrm{~h}$.

The commercial harvest point was established when the first three floral buds show the corolla color (Schwab et al., 2015a). At this time, the following parameters were evaluated in both growing periods: the number of florets, floral stem length (measured from the soil surface to the tip of the spike), spike size (should be at least $40 \%$ of the total size of the stem), and stem diameter (measured at the base of the insertion of the first floret). The standards for the commercialization of gladiolus flowers are shown in Table 1.

Table 1: Classification criteria of the commercial standard for A1 gladiolus stems. Stems shorter than $0.75 \mathrm{~m}$ and longer than $1.10 \mathrm{~m}$ are downgraded to $\mathrm{A} 2$.

\begin{tabular}{ccc}
\hline Standard & $\begin{array}{c}\text { Floral stem } \\
\text { length }(\mathrm{cm})\end{array}$ & $\begin{array}{c}\text { Floral stem } \\
\text { diameter }(\mathrm{cm})\end{array}$ \\
\hline 75 & 75 & Min. 0.5 \\
90 & 90 & Min. 0.8 \\
1.10 & 110 & Min. 1.0 \\
\hline
\end{tabular}

Source: Veiling Holambra Cooperative (2019).

Leaf area was estimated in all plants at 66 DAP, for both growing periods, using a mathematical model developed in a specific methodology for Amsterdam gladiolus, as proposed by Schwab et al. (2014) (Equation 3):

$\mathrm{LA}=0.664(\mathrm{~L} \mathrm{~W})$

Where LA is leaf area $\left(\mathrm{cm}^{2}\right), \mathrm{L}$ is leaf length $(\mathrm{cm})$, and W is the greatest leaf width $(\mathrm{cm})$.

Gladiolus sensitivity to water deficit was evaluated according to Doorenbos and Kassam (1979) (Equation 4). 


$$
\left(1-\frac{y_{r}}{y_{m}}\right)=K_{y}\left(1-\frac{E T_{r}}{E T_{m}}\right)
$$

Where $Y_{r}$ is real yield $(\mathrm{cm}), Y_{m}$ is maximum or potential yield, $\mathrm{Ky}$ is yield response factor, $\mathrm{ET}_{\mathrm{r}}$ is real crop evapotranspiration, and $\mathrm{ET}_{\mathrm{m}}$ is maximum crop evapotranspiration. In this study, the variables related to commercial quality (length, diameter, and size of the floral stem spike) were used as crop yield (Y), while the water volume applied was used as a measure of crop evapotranspiration (ET). According to Doorenbos and Kassam (1979), Ky can be classified as follows: low (Ky $<0.85)$; low/medium $(0.85<\mathrm{Ky}<1.00)$; medium/high $(1.00$ $<\mathrm{Ky}<1.15)$ and high $(\mathrm{Ky}>1.15)$.

Two undisturbed soil samples were collected to construct the soil water retention curve. Water retention curves were determined using the HYPROP (UMS) device and adjusted in HYPROP-FIT software according to the model of van Genuchten (1980), as shown in Equations 5 (winter/spring cycle) and 6 (autumn/winter cycle):

$$
\begin{aligned}
& \theta=0.263+\frac{0.342}{\left[1+(0.0367 \mathrm{~h})^{1.721}\right]^{0.4189}} \\
& \theta=0.444+\frac{0.329}{\left[1+(0.0937 \mathrm{~h})^{2.191}\right]^{0.5435}}
\end{aligned}
$$

Where " $\theta$ " is soil moisture content in $\mathrm{cm}^{3} \mathrm{~cm}^{-3}$, and " $\mathrm{h}$ " is matric potential in $\mathrm{kPa}$.

Analysis of variance was performed for the data at a $5 \%$ probability level, and when significant, it was further subjected to regression analysis.

The analysis of variance (ANOVA) was performed after verifying the normality and homogeneity of the residues using Shapiro-Wilk's and Bartlett's tests, respectively, at $5 \%$ of probability. When data was significant according to the $\mathrm{F}$ test at $5 \%$ of probability, the regression analysis was carried out using Student's t-test to verify the fit of the linear and quadratic models to the biometric data and stomatal conductance, in response to the irrigation levels. The models were chosen based on the lowest level of significance (p-value) and the highest coefficient of determination. For cases in which the same regression model was selected, depending on the treatments, the Graybill (2000) identity test was applied at the level of 5\% probability using the $\mathrm{F}$ test. When the models were considered identical, only one equation was generated to represent these models. All analyzes were performed with the computer programs, $\mathrm{R}$ (3.6.0) and Sisvar (5.6).

\section{RESULTS AND DISCUSSION}

In the first cycle (from $09 / 07 / 18$ to $11 / 27 / 18$ ), the temperature reached maximum values above $50{ }^{\circ} \mathrm{C}$, with the highest being $52.4^{\circ} \mathrm{C}$, on the 58th day after planting (DAP) (Figure 1A). The minimum temperature recorded was $14.9^{\circ} \mathrm{C}$, at $3 \mathrm{DAP}$.

In the autumn/winter cycle, the maximum temperature recorded was $45.7^{\circ} \mathrm{C}$, with a minimum of $16.0^{\circ} \mathrm{C}$. In the winter/spring cycle, lower temperatures were recorded in the first few days, with more significant oscillations over time, while in the autumn/winter cycle, temperatures were initially higher, also showing oscillations over time, but in a smaller proportion.

The maximum and minimum values recorded for relative humidity (RH\%) in the autumn/winter cycle were $89.8 \%$ and 21.2 , respectively, while in the winter/ spring cycle, it was $88.8 \%$ and $18.7 \%$, respectively, with oscillations in both periods (Figure 1B).

To better evaluate the production cycle of gladiolus while considering the biological aspects, the thermal sum in degree-days was calculated for each phase of the cycle (Figure 2).

During the evaluation of the accumulated thermal sum, the emergence period had the same duration in degree-days in all treatments of the winter/spring cycle $\left(287^{\circ} \mathrm{C}\right.$ day). This behavior was observed because the treatments had the same duration from planting to emergence (PL-VE). In the autumn/winter cycle, the control treatment accumulated $311^{\circ} \mathrm{C}$ day in 12 days of emergence, while the other treatments accumulated $338^{\circ} \mathrm{C}$ day in 13 days for emergence.

In the winter/spring cycle, plants grown with the $100 \%$ irrigation level required $1.493{ }^{\circ} \mathrm{C}$ day to reach the reproductive phase (marked by the beginning of spike formation) while plants under the same level of irrigation cultivated in autumn/winter required a more significant accumulation of $1.533^{\circ} \mathrm{C}$ day. By comparing this result with that of the $45 \%$ treatment, it is possible to note that accumulations of $1.726^{\circ} \mathrm{C}$ day in winter/spring and $1.702{ }^{\circ} \mathrm{C}$ day in autumn/winter were necessary to reach the reproductive phase. From emergence to spike formation (reproductive phase), there was a difference of $233{ }^{\circ} \mathrm{C}$ day for irrigation level of $45 \%$ compared to that of $100 \%$ in winter/spring, and this difference was equal to $169^{\circ} \mathrm{C}$ day in autumn/winter. 

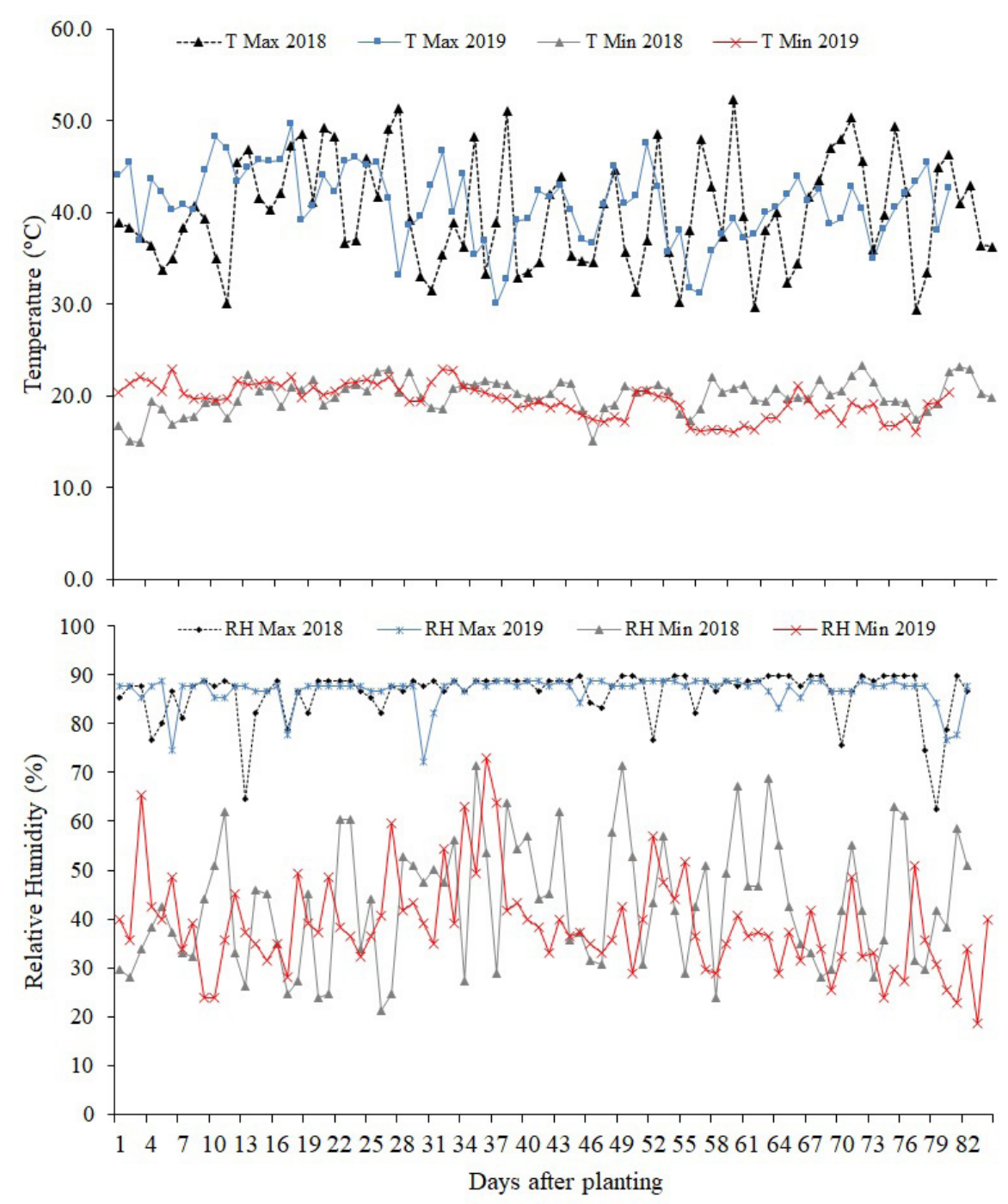

Figure 1: Daily maximum (Max) and minimum (Min) air temperatures (A) and daily relative humidity (B) recorded inside the greenhouse along the experimental periods for the winter/spring 2018 cycle and autumn/winter 2019 cycle.

Similar results were obtained during the phase from spike formation to harvest (reproductive phase), with lower values for $45 \%$ irrigation level than the higher irrigation level. The differences were 9 and $3{ }^{\circ} \mathrm{C}$ day more for the $45 \%$ treatment in winter/spring and autumn/winter cycles, respectively.

During the winter/spring cycle, the reproductive phase of the stems occurred under higher temperatures (14.9 to $\left.52.4^{\circ} \mathrm{C}\right)$ than those recorded for the autumn/winter cycle $(16$ to $45.7^{\circ} \mathrm{C}$ ), which explains the more significant accumulation of degree-days in winter/spring cycle (Figure 2A).

Among the treatments, the variation in the duration of the vegetative phase was higher than that of the reproductive phase, indicating that the different irrigation levels influenced the former in a more pronounced manner. The reduction in water supply for plants can result in longer vegetative phases; for example, the $45 \%$ treatment required greater accumulation of degree-days to reach the spike development phase in both cycles. Water availability is directly proportional to the development cycle (Bartz et al., 2017), and reduction in water availability reduces the developmental rate causing a longer duration of the vegetative phase (Farooq et al., 2009). Longer cycles can delay the harvest beyond the farmer's planning and cause financial loss to the farmer, mainly when the production is focused on a specific marketing date. 


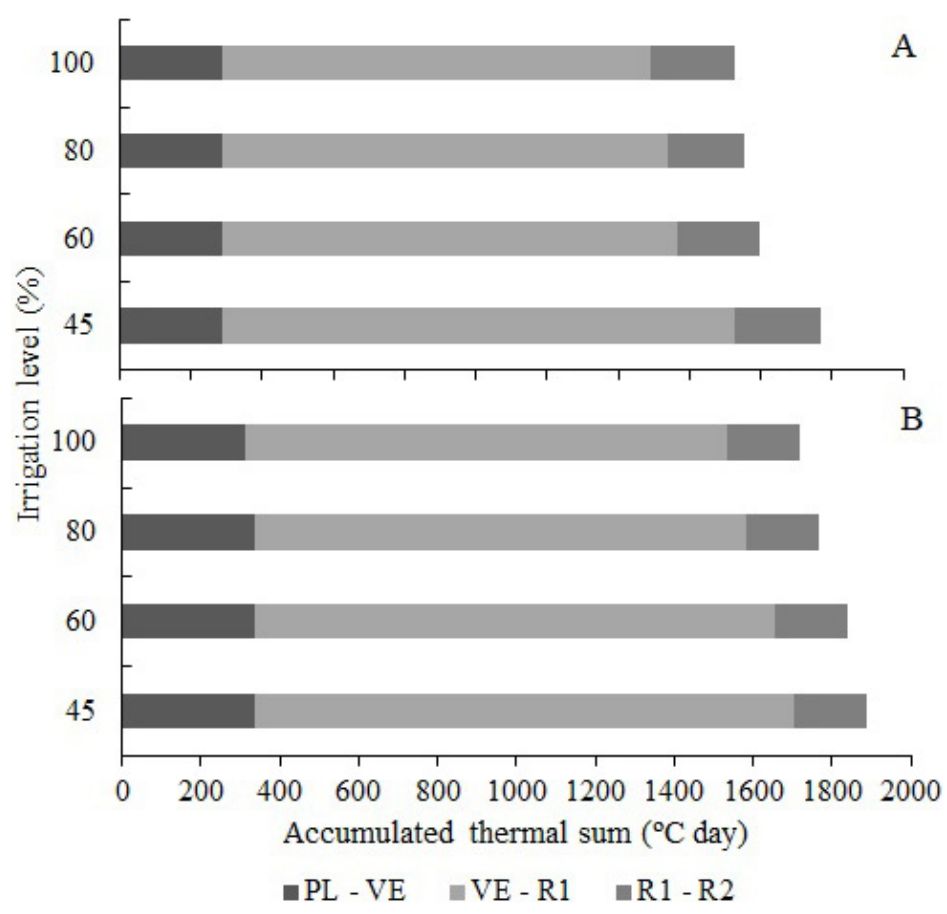

Figure 2: Duration (day and ${ }^{\circ} \mathrm{C}$ day) of the phenological phases of Amsterdam gladiolus cultivated under different levels of irrigation in the winter/spring cycle (A) and autumn/winter cycle (B). PL - VE: planting - emergence, VE R1: emergence - heading, and R1 - R2: heading - blooming.

In the first two weeks of both cycles, the volume of water applied was relatively low due to the wetting performed before planting, but after installation of the treatments in the third week, there was an increase in the volume of water applied. Throughout the cultivation period, the system was triggered 70 times in the winter/ spring cycle (Figure $3 \mathrm{~A}$ ) and 56 times in the autumn/winter cycle (Figure $3 \mathrm{~B}$ ). As the system operates according to the requirement of the plant, the higher frequency of actuation during the first growing period indicates that there was a greater demand for water by the plant in this cycle; however, it does not necessarily indicate a larger volume applied. It is worth mentioning that all the treatments were irrigated simultaneously by maintaining the proportion of volumes according to the flow rate of the emitters.

There was an increase in the volume of water applied from the seventh week in both cycles when the plants were at 42 DAP, and it reached the highest volume in the tenth week (from 63 DAP in both cycles). This period coincides with the spike development phase in plants under $100 \%$ irrigation (control treatment). The increase in the volume of water applied to the crops throughout the cycle is not linear, but it is in fact, dependent on the phase at which the crop is, with maximum water required during the phase of inflorescence formation and opening (Pereira et al., 2005). Considering that the water requirement of plants in the L4 treatment was responsible for triggering the irrigation system, it is possible to infer that the larger water volume applied from the tenth week (Figure 3) occurs due to the greater need for water at the spike formation phase, which is also one of the most sensitive to water stress (Pereira et al., 2009).

There were no significant interactions between the factors studied (irrigation level and growing period) for the leaf area $(p<0.476)$; however, the irrigation levels significantly influenced this variable $(\mathrm{p}<0.000)$. Although there is no major difference between the growing periods, the average of leaf area during the autumn/winter period was higher than those in winter/spring, varying from 854.6 to $1254.4 \mathrm{~cm}^{2}$ for the first growing period and from 940.3 to $1300.9 \mathrm{~cm}^{2}$ for the second one (Figure 4).

The adjustment of the leaf area data to the linear model suggests that higher values were obtained when a higher amount of water was applied (Figure 4). Apart from its primary role in $\mathrm{CO}_{2}$ fixation, leaves also play a significant role in water and nutrient usage in plants (Farooq et al., 2009). Thus, any modification in the morphology of the leaves may influence the progress of important physiological processes, like photosynthesis. 


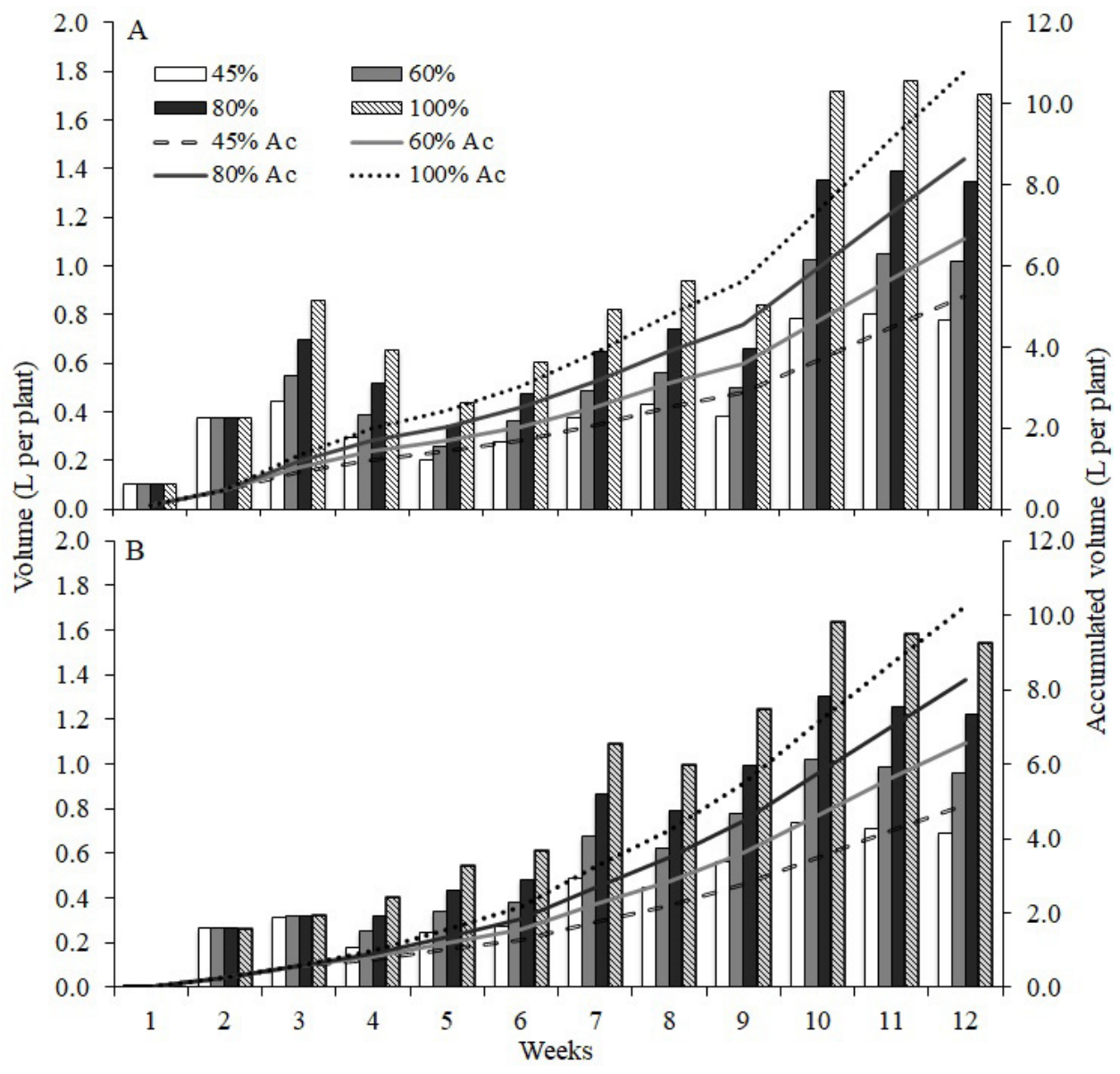

Figure 3: Accumulated volume of water applied (L per plant) weekly and over the cycle for each treatment in the winter/spring (A) and autumn/winter (B) cycles.

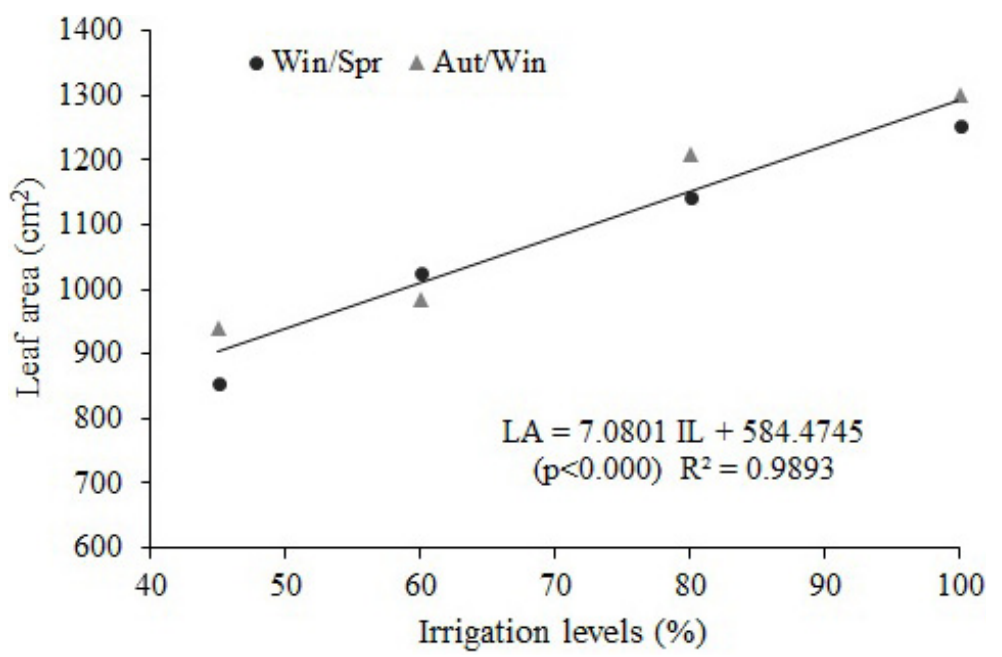

Figure 4: Plant leaf area (LA) of gladiolus Amsterdam at 66 DAP (days after planting) in winter/spring (Win/Spr) and autumn/winter cycles (Aut/Win), as a function of irrigation level (IL). 
In some plants, reduction in the water supply inhibits stem growth and leaf expansion (Taiz; Zeiger, 2017), which might be one reason for a smaller leaf area in the treatments of $45 \%$ and $60 \%$ of crop water requirement. A smaller leaf area can also occur as an adaptation of the plant to water stress conditions, since the decrease in leaf area represents a smaller transpiration surface; thus, avoiding rapid water depletion from soil (Taiz; Zeiger, 2017). When studying the effect of water deficit in gladiolus plants, Mazzini-Guedes et al. (2017) observed that plants obtained after applying $25 \%$ of field capacity treatment have lower values of total plant height and number of leaves.

The result of stomatal conductance analysis is represented in Figure 5. There was no significant difference observed for the $10 \mathrm{~h}$ period, and only the evaluations at $12 \mathrm{~h}$ $(p<0.025)$ and $14 \mathrm{~h}(\mathrm{p}<0.017)$ showed significant variations. On comparing the values of $100 \%$ irrigation level to those of the $45 \%$ treatment, it is possible to note increments in stomatal conductance of $77.2 \%$ and $71.4 \%$ at $12 \mathrm{~h}$ and $14 \mathrm{~h}$, respectively.

Over the period, there was a reduction in stomatal conductance in the afternoon, at $12 \mathrm{~h}$ period, and more distinctly at $14 \mathrm{~h}$ period when compared to the morning time. Overall, the values ranged from 234.95 to $443.35 \mathrm{mmol} \mathrm{m}^{-2} \mathrm{~s}^{-1}$.

The stomatal conductance for most herbaceous plants oscillates between 300 and $500 \mathrm{mmol} \mathrm{H}_{2} \mathrm{O} \mathrm{m}^{-2} \mathrm{~s}^{-1}$ (Larcher, 1995). It can be noted that the values found for the different treatments in the morning hours are within the expected range for herbaceous plants but decreases below 300 in the afternoon for the treatments with a more significant water deficit. Thus, the water deficit in treatments that received fractions of the required crop water promoted a reduction in stomatal conductance at the evaluated times. Such reductions were more pronounced in plants that received $45 \%$ of the crop water requirement. These results suggest that plants subjected to water deficit tend to reduce stomatal conductance, especially at the hottest times of the day, due to stomatal closure, which is an immediate response to water stress to reduce water loss by transpiration (El Yamani et al., 2020).

Water deficit leads to the loss of cell turgor and accumulation of abscisic acid (ABA), which is the promoter of stomatal closure. The closure of stomata reduces gas exchange and consequently leads to the reduction of photosynthesis (Taiz; Zeiger, 2017). Changes in the plant's hydration interfere with the movement of stomata, and it is only open when the guard cells are turgid (Oliveira et al., 2017). Since the stomatal movement is the primary mechanism controlling gas exchange in higher plants, and the influx of $\mathrm{CO}_{2}$ during the photosynthesis process (Silva et al., 2015), the low availability of water in the soil can directly interfere in this process.

No significant interaction was observed between the period and irrigation levels for the commercial variables, but there were single effects of the growing periods and the irrigation levels applied to the crop, which significantly influenced the variables $(\mathrm{p}<0.000)$, and the data fitted to a linear regression model (Figure 6). In the first cycle, the increments observed in the treatment L4 as compared to the treatment of higher water deficit (L1) were $24.75 \%, 30.36 \%$, and $28.57 \%$ for floral stem length, spike length, and floral stem diameter, respectively; and in the second cycle, the increments were 14.4, 22.4 and $11.1 \%$, respectively. These characteristics are essential for the classification of the stems for the cut flower market of gladiolus.

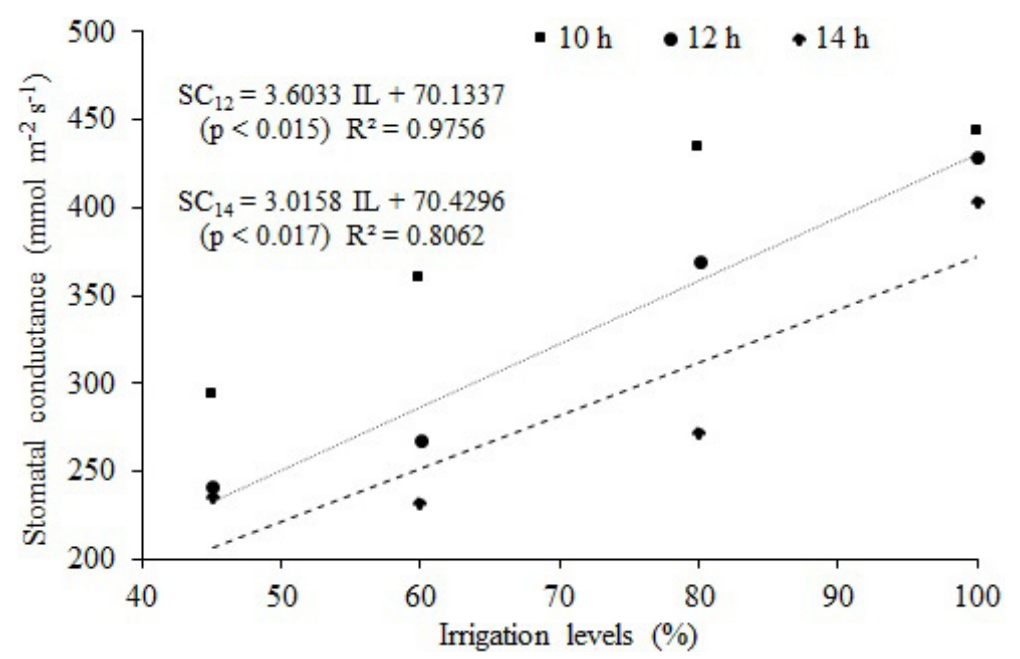

Figure 5: Stomatal conductance (SC) of gladiolus plants at 40 days after planting in the autumn/winter cycle, and evaluated at three periods of the day as a function of irrigation level (IL). 

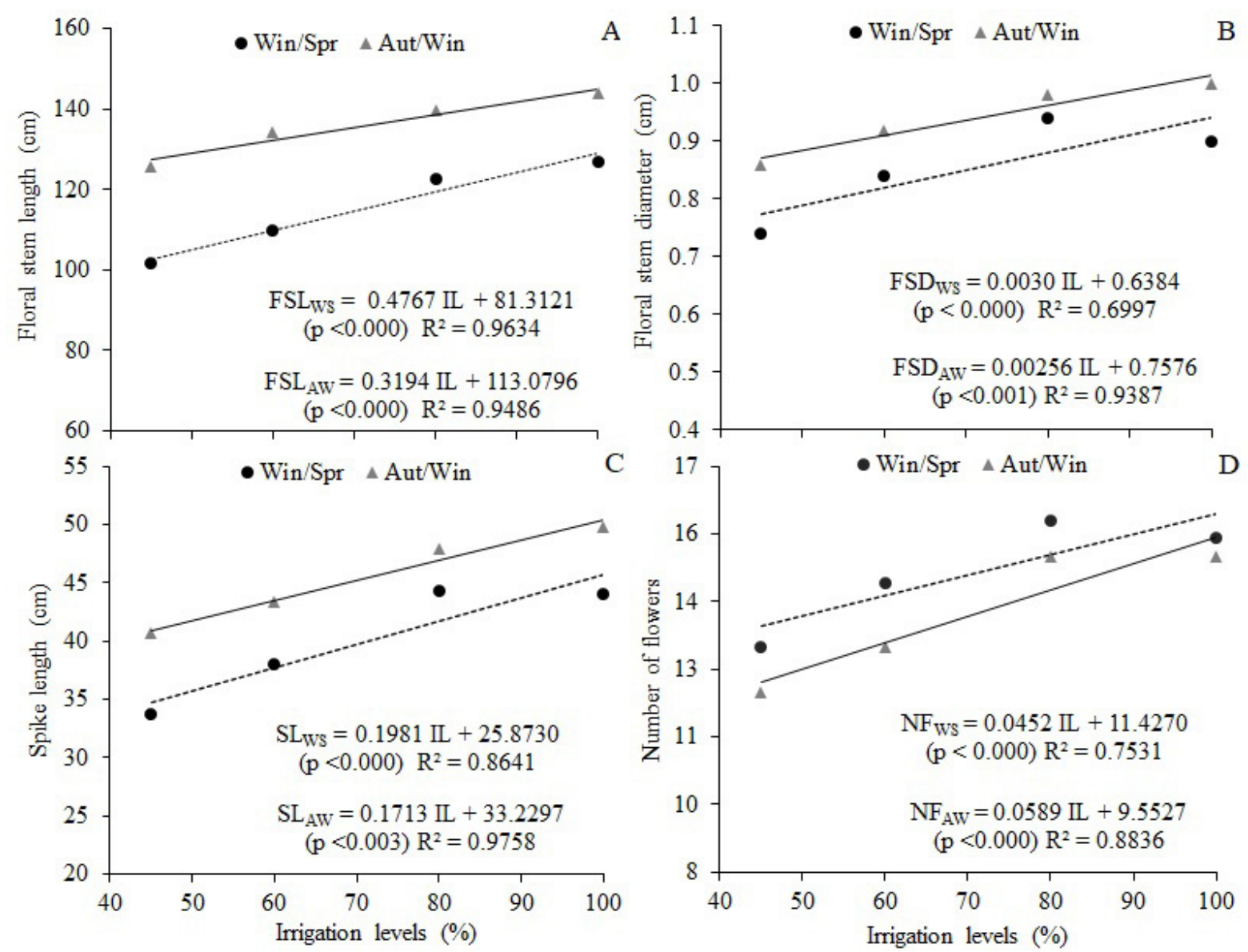

Figure 6: Floral stem length (FSL) (A), floral stem diameter (FSD) (B), spike length $(S L)(C)$, and the number of flowers of gladiolus (NF) (D) belonging to the Amsterdam variety in the winter/spring (Win/Spr) and autumn/ winter cycles (Aut/Win), as a function of irrigation level (IL).

All commercial variables evaluated showed significantly higher values in the autumn/winter cycle $(\mathrm{p}<0.000)$ than the winter/spring cycle. In the treatment of $45 \%$ irrigation, the floral stem length was $23.5 \%$ higher in the second cycle, while the spike length and diameter increased by $20.77 \%$ and $28.6 \%$, respectively, in the second cycle.

Contrary to agricultural crops, whose main parameter of commercial interest is the yield obtained, for ornamental plants, yield without quality has no benefit because the quality standard requirements for the main ornamental species are dependent on qualitative parameters (Cooperativa Veiling Holambra, 2019). The decline in visual qualities is the main effect of water stress on ornamental species (Nazemi Rafi; Kazemi; Tehranifar, 2019). Such negative performance of gladiolus plants under water stress was observed in $45 \%$ irrigation treatment, whose values were lower than those found in the other treatments for all variables analyzed. Cell expansion is the most affected process under water deficit conditions, causing a reduction in stem growth and leaf expansion (Taiz; Zeiger, 2017). Thus, the increase in the applied irrigation level promoted more significant growth and development of the floral stem, leading to increments that made it possible to meet the requirements of the quality standards of the gladiolus cut flower market.

A more extended spike tends to make the stem more attractive since it is the portion of the stem where the flowers are attached. As the stem length varies, spike length also varies, suggesting that shorter stems produce shorter spikes (Tomiozzo et al., 2018). This may explain the occurrence of an increase in spike length as the length of the floral stem increases in both cycles. 
Stems shorter than $75 \mathrm{~cm}$ were not observed in any of the cycles. Of all stems evaluated in the winter/ spring cycle, $61.7 \%$ can be classified as standard $90(\mathrm{~cm})$, $20 \%$ as standard $110(\mathrm{~cm})$, and $18.3 \%$ as standard 75 (cm). Among the stems produced under $80 \%$ and $100 \%$ irrigation levels, $48.3 \%$ and $31.7 \%$, respectively, were obtained in the maximum quality standard (standard 110 ). However, under the $45 \%$ and $60 \%$ levels, stems in the maximum quality standard were not obtained in the winter/spring cycle. In the autumn/winter cycle, from the total stems produced, $38.7 \%$ are classified as standard $90,7.5 \%$ as standard 75 , and $53.8 \%$ as standard 110 , of which $28.1 \%, 37 \%, 61.5 \%$, and $75 \%$ are obtained in the treatments L1, L2, L3, and L4, respectively (Figure 7). Spike length should always meet the criterion of being equal to $40 \%$ of the total floral stem length (Cooperativa Veiling Holambra, 2019), which results in a minimum length of $44 \mathrm{~cm}$ for the entire stem in standard 110;36 $\mathrm{cm}$ in standard 90 , and $30 \mathrm{~cm}$ in standard 75 . Thus, it is observed that, among the irrigation levels of the stems cultivated in the winter/spring period, only the stems with
$80 \%$ and $100 \%$ levels obtained minimum spike length of standard 110 for commercialization. On the other hand, stems of standard 110 were obtained in all treatments of the autumn/winter cycle. Temperatures over $40{ }^{\circ} \mathrm{C}$ were recorded during the experimental period, resulting in temporary wilting of spikes during warmer phases of the day, with subsequent turgor recovery. Previous studies show that the high air temperatures (above $36.2{ }^{\circ} \mathrm{C}$ ) can cause damage to gladiolus plants, including temporary wilting of floral stems and burns in the sepals (Schwab et al., 2018). However, injuries are visually detected only in the reproductive period. Despite these high temperatures, it was possible to obtain a product suitable for the commercial standards, without having a declassified floral stem, which demonstrates the rusticity of the plant.

According to the results found for commercial variables, the quality of the gladiolus stem decreases as water deficit increases (Figure 7). Pereira et al. (2009) reported that gladiolus floral stems of better quality are obtained under lower levels of water deficit, and by keeping the stems close to field capacity.

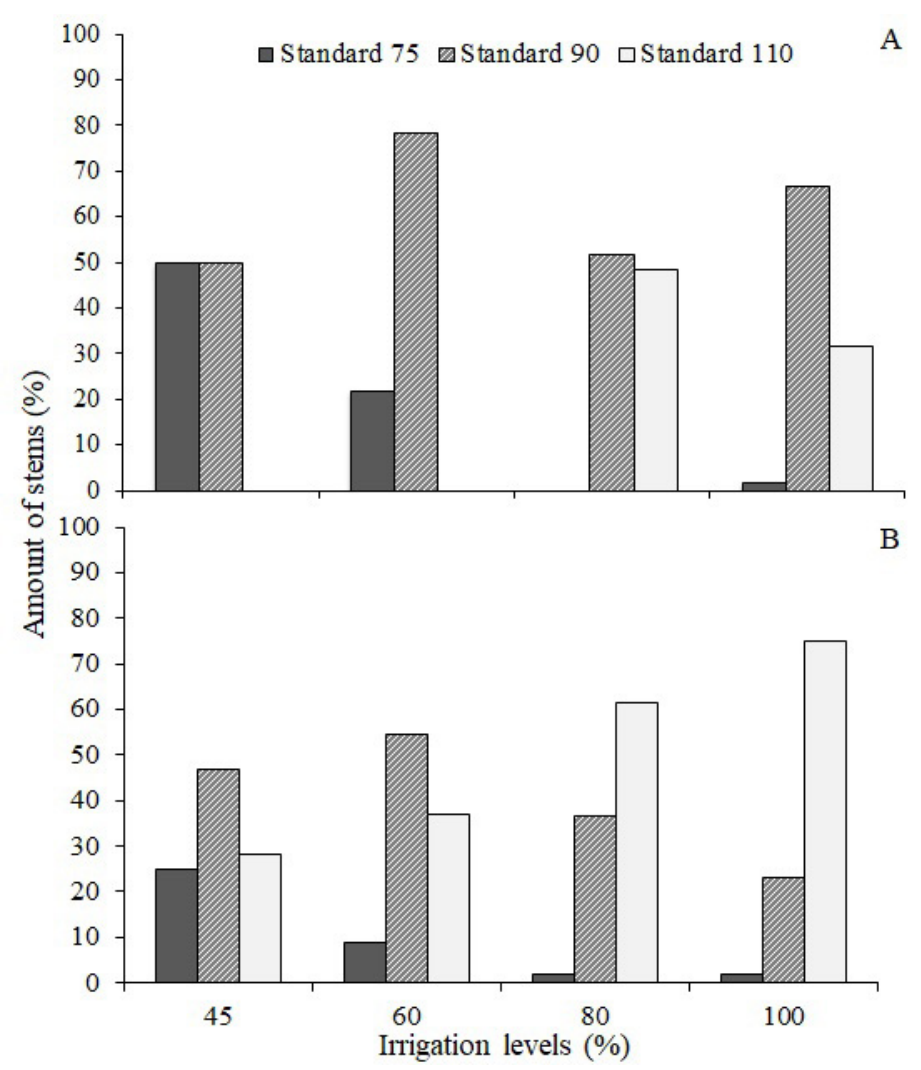

Figure 7: Commercial classification of gladiolus stems obtained in each treatment during the winter/spring 2018 cycle (A) and autumn/winter 2019 cycle (B), as a function of irrigation level. 
The Ky values found were all below 1 (Figure 8), indicating that for the periods evaluated, the variables such as floral stem length, spike length, and stem diameter of gladiolus $c v$. Amsterdam can be considered as a characteristic of low sensitivity to water deficit.

The highest Ky values were found in the winter/ spring cycle and were equal to $0.393,0.363$, and 0.474 for stem length, diameter, and spike length, respectively (Figure 8A, B, C). In the second growing period (autumn/ winter), the values for these parameters were reduced to $0.237,0.271$, and 0.365 , respectively (Figure $8 \mathrm{D}, \mathrm{E}, \mathrm{F}$ ). Based on the Ky values obtained, we found that the crop is more sensitive to water deficit in the winter/spring cycle, when the water volumes applied are higher.

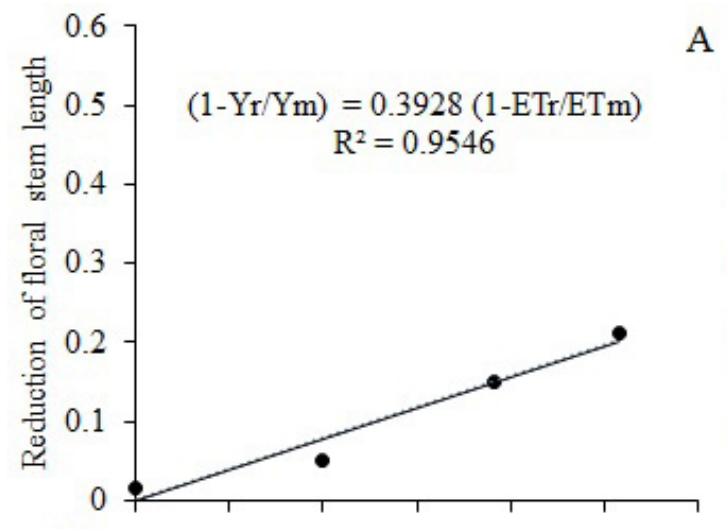

A 0.6 D

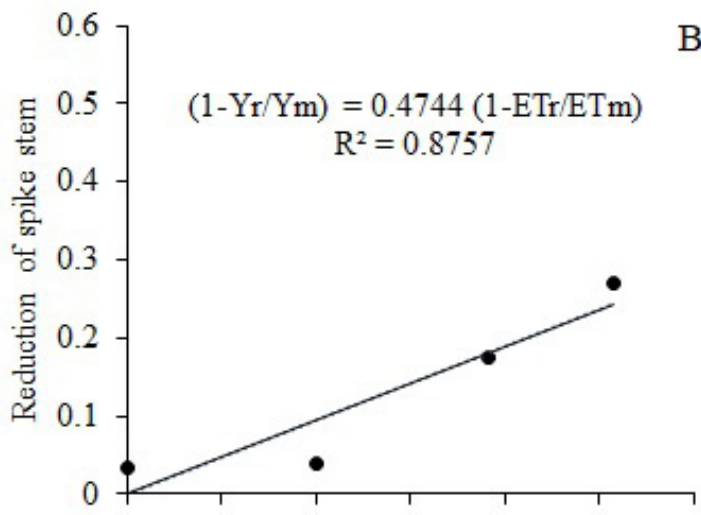

B
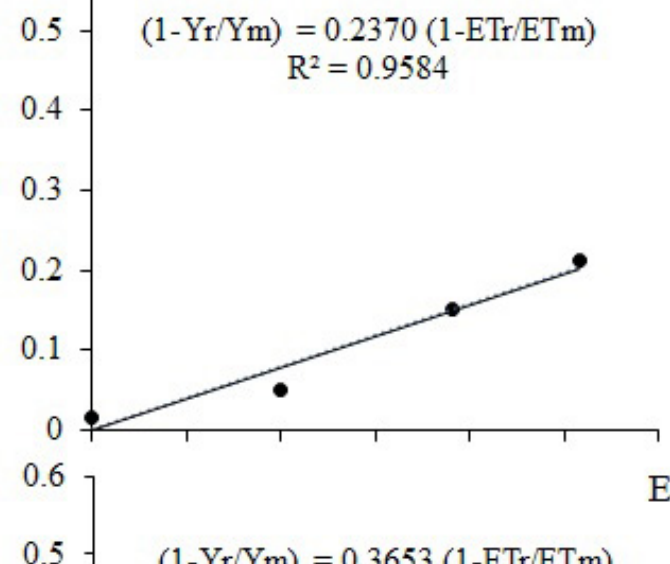

E
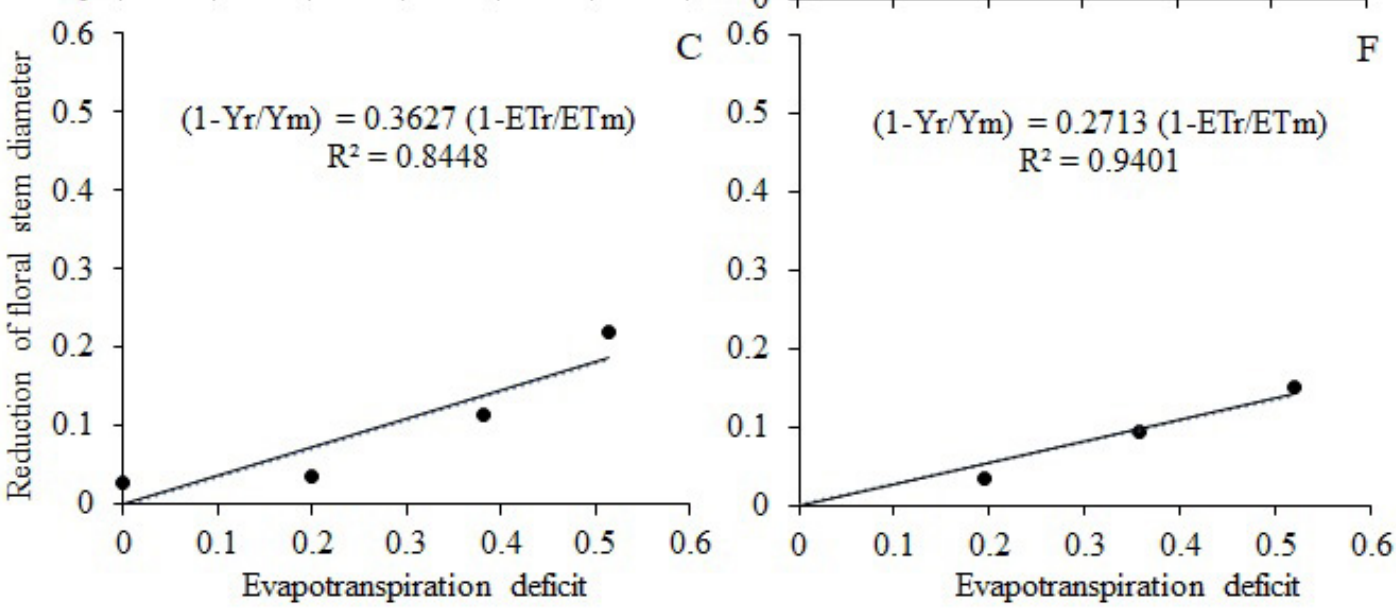

Figure 8: Yield response factor (Ky) of gladiolus for the variables, floral stem length, spike length, and diameter in winter/spring $(A, B, C)$ and autumn/winter $(D, E, F)$ cycles, respectively. 
Gladiolus is a rustic plant and manages to maintain its production at commercial levels even under conditions of limited water supply. In these conditions, the crop undergoes an elongation of the cycle and produces stems of less commercial value; but still marketable. Despite the low sensitivity to water deficit, it should be pointed out that, due to the need for fitting into the commercial classification criteria, even small reductions in commercial quantitative parameters are sufficient to classify the stems as lower grade products or disqualify them. It is necessary to prioritize the production of stems with higher quality, even if the crop is considered to have low sensitivity to water deficit according to the data exposed. In conclusion, irrigation that meets the water demand of the crop contributes to the crop reaching commercial production.

The results of this work are important to understand the environmental effects of cultivation in different seasons and study the quality of floral gladiolus stems grown under water restriction. This research shows the relationship between the seasons and the automatic irrigation and its effect on the extension of the gladiolus crop cycle, which allows for better planning of the flower harvest, as the market is punctual and efficient planning is necessary. In addition, the efficient use of water not only enables us to obtain quality flowers but also conserves this depleting natural resource.

\section{CONCLUSIONS}

Gladiolus crops have low sensitivity to water deficit conditions, but to obtain the flower stems of better commercial classification, $100 \%$ water replacement in the soil is required. However, depending upon the regional water availability scenario or seeking the maximization of farmers' profit, the $80 \%$ irrigation level can be considered advantageous. Higher levels of water deficit imply an increase in the crop vegetative phase, with more significant accumulation of degreedays and longer cycle duration, resulting in a late harvest and loss of the marketing period, with a potential financial loss to farmers whose production is intended for a specific date. All commercial variables evaluated showed significantly higher values in the autumn/winter cycle than the winter/spring cycle.

\section{REFERENCES}

BARBOSA, J. G. Palma-de-Santa-Rita (Gladíolo) produção comercial de flores e bulbos. Viçosa: Editora UFV, 2011, 113p.
BARTZ, A. C. et al. Soma térmica em arroz de terras baixas irrigado por aspersão. Pesquisa Agropecuária Brasileira, 52(7):475-84, 2017.

CASARES, M. C. et al. Potential use of germicides in vase solutions for gladiolus 'White Friendship'. Ornamental Horticulture, 23(1):79-87, 2017.

COOPERATIVA VEILING HOLAMBRA. Padrão de qualidade: Gladíolo de corte, 2019. Available in: <http://veiling.com. br/uploads/padrao/gladiolo-fc.pdf $>$. Access in: January, 15, 2019.

DOORENBOS, J.; KASSAM, A. H. Yield response to water. Rome: Food and Agriculture Organization of the United Nations, 1979, 193p.

EL YAMANI, M. et al. Leaf water status, physiological behaviour and biochemical mechanism involved in young olive plants under water deficit. Scientia Horticulturae, 261:(108906):1-10, 2020.

FAROOQ, M. et al. Plant drought stress: Effects, mechanisms and management. Agronomy for Sustainable Development, 29:185-212, 2009.

FREIRE, L. R. Manual de calagem e adubação do Estado do Rio de Janeiro. Embrapa Solos-Livro técnico (INFOTECA-E), 2013, 430p.

GOMES, D. P. et al. Growth and production of tomato fertilized with ash and castor cake and under varying water depths, cultivated in organic potponics. Acta Scientiarum. Agronomy, 39(2):201-209, 2017.

GRAYBILL, F. A. Theory and application of the linear model. Belmont: Duxbury, 2000, 704p.

JUNQUEIRA, A. H.; PEETZ, M. D. S. Sustainability in Brazilian floriculture: Introductory notes to a systemic approach. Ornamental Horticulture, 24(2):155-162, 2018.

LARCHER, W. Physiological plant ecology. 3. ed. Berlin, Heidelberg, New York: Springer-Verlag, 1995, 506p.

MAZZINI-GUEDES, R. B. et al. Management of corm size and soil water content for gladiolus flower production. Ornamental Horticulture, 23(2):152-159, 2017.

MEDICI, L. O. et al. Automatic controller to water plants. Scientia Agricola, 67(6):727-730, 2010.

NAZEMI RAFI, Z.; KAZEMI, F.; TEHRANIFAR, A. Effects of various irrigation regimes on water use efficiency and visual quality of some ornamental herbaceous plants in the field. Agricultural Water Management, 212(2):78-87, 2019. 
OLIVEIRA, H. P. et al. Respostas fisiológicas de forrageiras ao déficit hídrico e baixas temperaturas. Nutritime Revista Eletrônica, 14(5):7008-7014, 2017.

OMETTO, J. C. Bioclimatologia vegetal. São Paulo: Agronômica Ceres, 1981, 440p.

PAIVA, P. D. O.; ALMEIDA, E. F. A. Produção de flores de corte. Vol. 1. Lavras, MG: Editora UFLA, 2013, 678p.

PEREIRA, J. R. et al. Consumo de água pela cultura do crisântemo cultivada em ambiente protegido. Engenharia Agrícola, 25(3):651-659, 2005.

PEREIRA, J. R. D. et al. Crescimento e produção de hastes florais de gladíolo cultivado sob diferentes tensões de água no solo. Ciência e Agrotecnologia, 33(4):965-970, 2009.

PEREIRA, M. T. J. et al. Applying wood ash and soil moisture on gladiolus (Gladiolus grandiflorus) cultivation. Australian Journal of Crop Science, 10(3):393-401, 2016.

REIS, M. V. et al. Profile of producer and retailer of flower and ornamental plant. Ornamental Horticulture, 26(3):367$38,2020$.

SCHWAB, N. T. et al. Dimensões lineares da folha e seu uso na determinação do perfil vertical foliar de gladíolo. Bragantia, 73(2):97-105, 2014.

SCHWAB, N. T. et al. A phenological scale for the development of Gladiolus. Annals of Applied Biology, 166(3):496-507, $2015 \mathrm{a}$.

SCHWAB, N. T. et al. Parâmetros quantitativos de hastes florais de gladíolo conforme a data de plantio em ambiente subtropical. Pesquisa Agropecuária Brasileira, 50(10):902-911, 2015b.

SCHWAB, N. T. et al. Temperatura base para abertura de floretes e antocrono em gladíolo. Ceres, 64(6):557-560, 2017.

SCHWAB, N. T. et al. Duration of cycle and injuries due to heat and chilling in gladiolus as a function of planting dates. Ornamental Horticulture, 24(2):163-173, 2018.
SHILLO, R.; HAVELY, A. H. The effect of various environmental factors on flowering of gladiolus. IV. Interaction of environmental factors - General discussion. Scientia Horticulturae, 4(2):157-162, 1976.

SILVA, A. R. A. et al. Coeficientes de sensibilidade ao déficit hídrico para a cultura do girassol nas condições do semiárido cearense. Revista Brasileira de Agricultura Irrigada, 8(1):38-51, 2014.

SILVA, F. G. et al. Trocas gasosas e fluorescência da clorofila em plantas de berinjela sob lâminas de irrigação. Revista Brasileira de Engenharia Agrícola e Ambiental, 19(10):946-952, 2015.

SINGAB, A. N. B. et al. Shedding the light on Iridaceae: Ethnobotany, phytochemistry and biological activity. Industrial Crops and Products, 92(14):308-335, 2016.

SMITH, M; STEDUTO, P. Yield response to water: the original FAO water production function. Rome: Food and Agriculture Organization of the United Nations, p.110, 2012.

STRECK, N. A. et al. Desenvolvimento vegetativo e reprodutivo em gladíolo. Ciência Rural, 42(11):19681974, 2012.

TAIZ, L.; ZEIGER, E. Fisiologia e desenvolvimento vegetal. Artmed Editora, 2017, 888p.

TOMIOZZO, R. et al. Cycle duration and quality of gladiolus floral stems in three locations of Southern Brazil. Ornamental Horticulture, 24(4):317-326, 2018.

UHLMANN, L. O. et al. Gladiolus as an alternative for diversification and profit in small rural property. Ornamental Horticulture, 25(2):200-208, 2019.

VAN GENUCHTEN, M. T. A closed form equation for predicting the hydraulic conductivity of unsaturated soils. Soil Science Society of America Journal, 44(5):892-898, 1980. 